\title{
INTERPERSONAL COMMUNICATION AS A SOLUTION FOR RESOLVING DIPLOMATIC CONFLICTS IN THE MALAY SULTANATES
}

\section{(Komunikasi Interpersonal sebagai Penyelesaian Konflik Diplomatik Kerajaan Melayu)}

\author{
Salmah Jan Noor Muhammad \\ salmahjan@upm.edu.my \\ Department of Malay Language \\ Faculty of Modern Languages and Communication \\ Universiti Putra Malaysia.
}

Published on: 1 June 2018

To Cite: Salmah Jan Noor Muhammad. (2018). Interpersonal communication as a solution for resolving diplomatic conflicts in the Malay Sultanates. Malay Literature 31(1), 47-68.

\begin{abstract}
Interpersonal communication is an important element in the management of a government organization. In diplomatic relations, interpersonal communication tests an individual's or a group's ability to convey the message of peace. The ability to convey information clearly and thus avoiding misunderstanding, especially in resolving conflicts that may occur, builds trust among governments. Without skill in interpersonal communication, it becomes difficult for a government to maintain existing relations, or build new ones. This research was carried out to (i) analyse the interpersonal communication implemented by the Malay Sultanates as the main mechanism in resolving diplomatic conflicts, and (ii) explain the implications of the implementation of interpersonal communication in resolving conflicts among kingdoms. Data was collected through library research, and this discussion focuses on Hikayat Hang Tuah and Al-Tarikh Salasilah Negeri Kedah as the primary material. The findings of this study show that the sending of envoys was an
\end{abstract}


effective strategy of interpersonal communication in solving conflicts that arose, whether in terms of existing or new diplomatic relations. These envoys employed various strategies in their interpersonal communication, which were key to the success of their missions. The findings also show that the administration and government of a kingdom stabilized with the development of its economy, politics, culture and society.

Keywords: interpersonal communication, conflict, diplomacy, government

\begin{abstract}
Abstrak
Komunikasi interpersonal merupakan elemen penting dalam pengurusan sesebuah organisasi kerajaan. Dalam hubungan diplomatik, komunikasi interpersonal dapat menguji kemampuan seseorang individu atau secara berkumpulan dalam menyampaikan mesej keamanan. Kebolehan dalam menyampaikan maklumat dengan jelas mampu mengelakkan kesalahfahaman terutamanya, dalam menyelesaikan konflik yang berlaku di samping dapat membina kepercayaan antara kerajaan. Tanpa kemahiran dalam hubungan komunikasi interpersonal, agak sukar sesebuah kerajaan meneruskan hubungan sedia ada mahupun yang ingin membina hubungan baharu. Kajian ini dilakukan untuk (i) menganalisis komunikasi interpersonal yang diimplementasi oleh pemerintah kerajaan Melayu sebagai mekanisme utama dalam penyelesaian konflik hubungan diplomatik, dan (ii) menghuraikan implikasi implementasi komunikasi interpersonal tersebut dalam menyelesaikan konflik yang wujud antara kerajaan. Data yang diperoleh menerusi kaedah kepustakaan dan bahan utama perbincangan berfokuskan pada Hikayat Hang Tuah dan Al-Tarikh Salasilah Negeri Kedah. Hasil dapatan menunjukkan bahawa penghantaran utusan kerajaan merupakan implementasi komunikasi interpersonal yang berkesan dalam menyelesaikan konflik yang wujud sama ada hubungan diplomatik tersebut telah terbentuk ataupun baharu dibentuk. Utusan kerajaan membina pelbagai strategi dalam mengimplementasikan komunikasi interpersonal yang merupakan kunci untuk mencapai misi mereka. Dapatan juga menunjukkan bahawa pemerintahan dan pentadbiran sesebuah kerajaan semakin mantap dengan perkembangan kemajuan ekonomi, politik, budaya dan sosial.
\end{abstract}

Kata kunci: komunikasi interpersonal, konflik, diplomatik, kerajaan 


\section{INTRODUCTION}

Interpersonal communication is the constant interaction and sharing of information that takes place between individuals, or among groups of people. The aim of interpersonal communication is to clarify certain issues or to come to an agreement in solving any problem that arises face to face. This is in line with the opinion of Adler, Rosenfeld and Towne (1999), who state that interpersonal communication is a process of information exchange that involves communicators from within the same or different environments, and which is influenced by such interferences as external, physiological and psychological barriers. This is further supported by the views of Pearson and Nelson (2000), who state that among the reasons for interpersonal communication are the need to resolve problems and conflicts, to share information, and to improve one's self-image. Therefore, interpersonal communication requires an individual to have a high degree of skill.

In interpersonal communication, attention should be paid to nine important elements, namely eye contact, posture and body language, gestures or facial expressions, clothing and appearance, pitch and tone of voice, language, and pausing to allow feedback by the listener (Zulkifli, 2000). Both sender and receiver of the communication use more than one sense to receive information, message and the resulting response (Mohd Safiee et al. 2008). Response in this kind of communication is quick, lively and immediate (Mansor, Ramli \& Shawaluddin, 1984). In international relations, interpersonal communication is much stressed upon, and is an important aspect in forging diplomatic relations. According to Salmah Jan (2015, p. 136), diplomacy is the relationship involving two or more governments, who share a common aim and wish to fill an existing void in government and administration. Generally, the ruler will send an envoy as a representative to establish or strengthen diplomatic relations between governments. Therefore, the envoy selected for this task should be one who is skilled and seen as a well-rounded person. In the third chapter of Bustan al-Salatin, Clause 5 lists the ten characteristics of a good envoy:

Syarat yang pertama, hendaklah ia takut akan Allah Taala lagi teguh agamanya. Syarat yang kedua, hendaklah ia ada pengetahuan. Syarat yang ketiga, hendaklah ia elok parasnya. [Syarat yang keempat, hendaklah ada ia kepercayaan dan jangan ia berbuat khianat akan rajanya kerana hawa nafsunya.] ... Syarat yang kelima, hendaklah utusan itu fasih lidahnya dan baik suaranya, syarat yang keenam hendaklah ada ia bijaksana ... 
Syarat yang ketujuh, hendaklah ada wazir itu utusan berani pada barang melakukan pekerjaan rajanya. Syarat yang kelapan, hendaklah ia baik kelakuannya lagi aqil ... Syarat yang kesembilan, hendaklah utusan itu murah lagi bangsawan. Syarat yang kesepuluh, hendaklah ia jangan sangat tamak, jika sangat tamak ia, nescaya aiblah nama rajanya.

[The first condition is, he should fear Allah Most High and be strong in faith. The second condition is that he should be knowledgeable. The third condition, that he be fair of face. (The fourth condition, that he be trustworthy and never betray his King in pursuit of his own desires.) ... The fifth condition is that the envoy be fluent in speech, and that his voice be pleasant, the sixth condition, that he be wise ... The seventh condition, that as an aide he be courageous in carrying out the charge of his King. The eight condition, that he be good in act and and intelligent ... The ninth condition, that he be kind and noble. The tenth condition, that he not be greedy, for if this greed will sully his King's good name.]

The fifth condition in this excerpt refers to skill in interpersonal communication. A leader or envoy that is not skilled in interpersonal communication will be the cause of conflict.

\section{CONFLICT AND THE IMPORTANCE OF INTERPERSONAL COMMUNICATION}

In reference to conflict, Newstorm and Davis (1997) state that conflict is a social legacy that can occur in all kinds of situations as a result of disagreement, controversy, or constant animosity between two or more parties. Ishak (2006, pp. 115-116) agrees with this view. He states that conflict is a condition involving two or more parties as a result of disparate aims to be achieved, incompatible activities in pursuit of aims or goals, differences in personality or aspirations, actions that thwart or harm the other, and conflicting parties displaying signs of enmity. With reference to the age of the old Malay Sultanates such as Melaka (Malacca), Aceh (Acheh), Johor Riau-Lingga and Kedah, external conflicts among governments did occasionally occur. Anecdotes of such conflicts are recorded in classical Malay manuscripts. An example is the warrior king, Raja Pahlawan, the envoy of Haru to Pasai in Sulalat al-Salatin. Raja Pahlawan is unable to control his interpersonal communication well while in Pasai to establish diplomatic relations. Conflict is set off through misunderstanding of the term 
"salam". On the part of the Pasaians, "salam" means "sembah" (greetings) but to the Haru party it means "willing to be protected".

\begin{abstract}
Adapun di dalam surat itu, "Salam paduka kakanda." Maka oleh khatib itu, "Paduka kakanda empunya sembah, datang kepada paduka adinda." Maka kata Raja Pahlawan, "Lain surat lain dibaca; salam dikata sembah." Maka oleh khatib itu dibacanya "sembah" juga. Maka berkata pula Raja Pahlawan, "Ah, lain surat, lain dibaca; remak mati di tanah Pasai, jangan mati di tanah Haru. Jika demikian anjing Pasai pun tahu akan sebuah sepatah." Maka dibaca juga oleh khatib Pasai itu "sembah".
\end{abstract}

[It was stated in the letter, "Salam, honourable elder brother." Thus the Khatib read, "Honourable elder brother, I receive your greetings as your honourable younger brother." So Raja Pahlawan said, "The letter states otherwise, and he reads otherwise; salam he reads as sembah." But still the Khatib read it as "sembah" (greetings). Then, Raja Pahlawan said, "Ah, the letter is different from what is read; it is better to die in this land of Pasai, than to die in Haru. For at least then a dog of Pasai will know the correct meaning of the word." But again the Khatib read it as "sembah".]

(A. Samad, 2010, p. 176).

This conflict would have been resolved had Raja Pahlawan taken it upon himself to study the circumstances and the ways in which the Pasaians communicated with outsiders. However, because of Raja Pahlawan's poor interpersonal communication skills, a small occurrence that could easily be resolved sparks a major conflict that results in killing and war among the two parties. This incident is an example of the failure of a government envoy to master interpersonal communication. Therefore, in order to ensure that diplomatic relations remain smooth, the ruler and the envoy must have good interpersonal communication skills in order to attract attention and resolve any arising conflicts with other kingdoms. The aim of this research is to study whether the interpersonal communication employed by the Malay Sultanates is a major mechanism in resolving diplomatic conflicts, and the implications of the application of such interpersonal conflicts in resolving conflicts between kingdoms.

The objectives of this study are to analyze the interpersonal communication employed by the Malay Sultanates as the main mechanisms in resolving 
diplomatic conflicts, and explaining the implications of such interpersonal communication in resolving conflicts among the various kingdoms. The discussion pertaining to these objectives will concentrate on two classical Malay manuscripts, that of Hikayat Hang Tuah and Al-Tarikh Salasilah Negeri Kedah, as the primary sources.

Hikayat Hang Tuah MSS 1713 in the collection of the Malaysian National Library is a tale of warriorhood describing from beginning to end how a lowly servant of the king named Hang Tuah is raised to the position of nobleman of Melaka, and is capable of bringing glory and honour to the Sultan's and his country's name on the world stage. The anonymouslycomposed Hikayat Hang Tuah has been identified as a World Heritage Document by the United Nations Educational, Scientific and Cultural Organisation (UNESCO) in 2001. Al-Tarikh Salasilah Negeri Kedah, written by Muhammad Hassan bin Dato' Kerani Muhammad Arshad by order of Tunku Ibrahim ibni Sultan Abdul Hamid, the regent, on 1 Rejab 1345 (5 January 1927).

This article will discuss the implementation of interpersonal communication as a mechanism in resolving conflict in order to maintain and strengthen diplomatic relations. In Hikayat Hang Tuah, the Melaka Sultanate and a kingdom on the Indian subcontinent are in conflict, while Al-Tarikh Salasilah Negeri Kedah focuses on the relationship between Kedah and Ligor.

\section{THE MELAKA SULTANATE AND THE INDIAN KINGDOMS -BLOOD IS THICKER THAT WATER}

Hikayat Hang Tuah documents that the Sultan of Melaka and Sang Jaya Nantaka, a King from the a kingdom on the Indian Subcontinent, were brothers. Sang Jaya Nantaka was at one time appointed the crown prince of Melaka. However, a false rumour was spread, stating that he was in collusion with evil forces to gain control of the throne, and he was stripped of this position. Thereupon, Sang Jaya Nantaka left the palace and lived as an ordinary fisherman in Kampung Bendahara (Kassim Ahmad,1997, pp. 79-81). Here, the seeds of discord between the Sultan of Melaka and Sang Jaya Nantaka were sown.

The conflict continued because Parmadewan, a rich merchant from the Indian Subcontinent, brought Sang Jaya Nantaka to the Indian Subcontinent to be crowned king there. Parmadewan was a keen believer in his prophetic 
visions, who foretold that this descendant of the gods would bring fortune to whatever kingdom he ruled.

Dalam nujumnya di tanah Melayu itu sekarang sudah diturunkan Allah Subhanahu wa Taala seorang raja dari keinderaan. Maka raja itu beranak laki-laki empat orang terlalu amat baik parasnya. Setelah dilihatnya dalam nujumnya maka Parmadewan pun fikir dalam hatinya, 'Adapun Benua Keling ini tiada beraja; baik aku berbelanjakan hartaku ini, aku hendak menjadikan raja dalam negeri ini kerana hartaku pun terlalu banyak; kerana harta dunia ini tiada gunanya ... Jika demikian baik aku pergi ke tanah Melayu itu sambil berniaga-niaga, supaya kupinta anak raja itu seorang kujadikan raja Benua Keling ini, supaya mashyur namaku disebut orang datang kepada akhir zaman, nama anak cucuku disebut orang jadi kaya; hiduplah namaku.'

[The vision said that in the Malay lands there had been sent by Allah Most High a king from heaven. And this king had four sons, who were each fair of face. When Parmadewan had seen this in his prophetic vision, he thought to himself, 'The Indian kingdom has no king; it is well for me to spend my wealth and appoint a king for it, because my wealth is too great; because this worldly wealth is of no use ... If it is so, it is better I leave for the Malay lands for trade, so that I may find a prince to be king of this Indian kingdom, so that my name will become well-known to people till the end of days, and my descendants will be known as successful people; in this way my name shall live on'.]

(Kassim, 1997, p. 82).

Parmadewan's request is not denied by the Sultan of Melaka, who allows him to bring his brother to the Indian Subcontinent. The Sultan only asks that Parmadewan takes good care of his brother and awards him a gift by way of expressing gratitude for this service. This gift is in the form of:

... perempuan yang baik paras dan pandai segala pekerjaan daripada suji dan sulam dua puluh orang dan gundik yang baik-baik sepuluh orang dan keris berhulu emas empat puluh bilah dan tombak bersampak emas empat puluh dan pedang berikat emas dua puluh bilah ... 
[... twenty beautiful maidens well-versed in all kinds of needlework, and ten good concubines and forty kris with gold handles and forty spears fixed with gold, and twenty gold-decorated swords ...]

(Kassim, 1997, p. 96)

This is a slap to the face for Sang Jaya Nantaka, because he has to endure unfair punishment. Firstly, he is the victim of slander and has been punished without due investigation. In other words, there was no communication that would have allowed him to defend himself. Secondly, he lives as an ordinary citizen, a treatment which, as a member of the royal family, Sang Jaya Nantaka does not deserve. Thirdly, he is exiled from Melaka to be made king elsewhere. This move is meant to weaken the opposing party or prevent the spread of their influence. According to Ab. Aziz (2003, p. 212), this happens because there is competition. When one pursues one's goals or interests without any thought for the other party, they opposing party will be willing to do anything possible to overcome their opponent, while at the same time ensuring that their goals are achieved. In the end, Sang Jaya Nantaka is crowned king of an Indian kingdom and takes the name Kisna Rayan.

This cold war does not continue for long for the Sultan of Melaka wishes to solve this internal conflict. In order to achieve this, the sultan sends Hang Tuah as an envoy representing Melaka. The sultan's intentions are to forge diplomatic ties with the Indian kingdom. According to Mohd Jamil (2011, pp. 114-115), the kingdom on the Indian Subcontinent is a large kingdom that has religious and trade links with the Malay archipelago. Apart from this, the Sultan of Melaka is certain that appointing Hang Tuah as envoy to visit the Indian Subcontinent is the right move as Hang Tuah has a proven track record, having visited other kingdoms such as Majapahit. Therefore, the application of interpersonal communication skills in resolving the conflict between the Sultanate of Melaka and the Indian kingdom centres on the envoy.

Noriah Mohamed (1997, p. xxxvi) states that Hang Tuah is a Malay intellectual is a master of religious knowledge, worldly knowledge, practical knowledge, the unseen arts, diplomacy, culture and customs. Hassan (2009, p. 149) calls Hang Tuah the defender of Malay culture while Lokman Abdul (2001, p. 103) says that Hang Tuah is loyal and dedicated to his king, one who has the characteristics of a warrior and is willing to sacrifice for his people 
and his religion. His success results in the influence of Melaka spreading further and it is because of this that Melaka becomes a great empire, well known in East and West in the early 15th and 16t centuries (Mohd Jamil, 2011, p. 118). Hang Tuah's background is a motivating factor for the Sultan of Melaka to choose him as the envoy representing Melaka.

In order to resolve the conflict between Melaka and the Indian kingdom, Hang Tuah arranges to meet Kisna Rayan personally, through Nala Sang Guna. Hang Tuah displays his fluency in the language of the Indian kingdom, the Nagaram language. This is an important move for Hang Tuah in order to attract the interest of Kisna Rayan, so that he takes interest in Hang Tuah's arrival in Bijaya Nagara. According to Anwar Ridhwan (2009), mastering a foreign language is an advantage, as it also allows insight into the psychology and culture of its speakers. Noriah Mohamed (2010, p. 82) is similarly of the opinion that learning different languages is not merely for ease of communication but also allows one to enter the culture of its speakers. $\operatorname{Lim}(2005$, p. 7$)$, too, believes that language and culture are closely related. Culture provides the arena for language to develop in a certain mould, while language reflects or displays the true form of culture and thinking of its people. The importance of knowing other languages facilitates two parties to interact and put themselves on the same plane with the values and culture of the other kingdom, as is proven by Hang Tuah. Hang Tuah realizes that one way to forge diplomatic ties is through the mastering of interpersonal communication. An important aspect of communication is building social relationships, that is, by understanding and respecting the similarities and differences between one another through fluency in another language.

Mendengar sembah Laksamana dalam bahasa Nagaram itu, maka Kisna Rayan dan bendahara mangkabumi dan segala raja-raja dan menteri yang mengadap itu pun hairan tercengang-cengang, kerana melihat Laksamana tahu bahasa Nagaram itu, kerana segala raja-raja dan menteri yang banyak itu berpilih yang tahu akan bahasa Nagaram itu. Maka Kisna Rayan pun gemar melihat laku Laksamana berkata-kata itu dengan bahasa Keling itu fasih lidahnya dan manis mukanya dan dengan merdu suaranya, patut ia berkata-kata itu.

[Hearing the Laksamana speak in the Nagaram tongue, Kisna Rayan and the bendahara mangkabumi, and the other rajas and ministers who were in audience with the king were caught by surprise, seeing that the Laksamana knew the Nagaram tongue, because all the assembled rajas 


\section{MALAY LITERATURE VOLUME 31 NUMBER 1 JUNE 2018}

and ministers knew the Nagaram tongue. And Kisna Rayan was pleased with the way the Laksamana spoke fluently and well in that Indian language, with a pleasant expression on his face and a pleasant voice, speaking becoming words.]

(Kassim, 1997, pp. 392-393)

As a result of the above, Kisna Rayan is surprised with Hang Tuah's language talent and, in an effort to get to know him better, asks Hang Tuah about his background. Here, Hang Tuah uses his skills in interpersonal communication when he states that he wishes not only to be a subject of Melaka but also of the Indian kingdom. Hang Tuah's diplomacy lies in the conciliatory tone that he takes. Despite all this, Kisna Rayan still feels slighted by his elder brother, the Sultan of Melaka:

\section{Excerpt 1:}

Setelah Kisna Rayan menegar sembah Laksamana demikian itu, maka titah baginda, "Hai Laksamana, terlalu sekali engkau berbahagia dan bertuah, maka engkau beroleh mengadap aku dan berkata-kata dengan aku dan berhadapan dengan aku. Pada hatiku, jika Raja Melaka sekalipun datang mengadap aku, sekianlah pertemuan aku dengan dia"

[Upon hearing the Laksamana's words, Kisna Rayan spoke, "O Laksamana, you are ever happy and fortunate, to be able to seek audience with me and speak to me and face me. In my mind, even should the King of Melaka come before me, this would be how I would receive him"]

(Kassim, 1997, p. 393)

\section{Excerpt 2:}

... maka titah raja, "Sungguhkah saudara kita hendak muafakat dengan kita maka Laksamana dan Maharaja Setia disuruhnya mengadap kita? Tatkala kita di Melaka, tiada muafakat dengan kita, melainkan bendahara dan si pengail juga muafakat dengan kita ...”

[... and the king said, "Is it true our brother wishes to reconcile and has sent his Laksamana and Maharaja Setia to seek audience with us? While 
we were in Melaka, he was not pleased with us, only the bendahara and the fisherman was on good terms with us ...”]

(Kassim, 1997, p. 393).

In these examples, Hang Tuah's main task is to repair the relationship between Kisna Rayan and the Sultan of Melaka, and establishing diplomatic relations. To achieve this, Hang Tuah is ready to face challenges thrown at him by Kisna Rayan. Among these is to tame a wild horse. Kisna Rayan's intention for doing so is to test Hang Tuah's physical strength and intelligence to bring the horse under control, even though this is seen as an attempt to kill Hang Tuah.

Maka di dalam hati Nala Sang Guna dan segala orang yang melihat kelakuan kuda itu, 'Adapun Laksamana ini hendak dibunuh oleh raja juga. Adakah kuda yang seperti harimau itu disuruh naik kepadanya?'

[Nala Sang Guna and those who saw the horse and how it behaved said to themselves, 'Surely the king intends to kill the Laksamana. Why else would he ask him to ride a horse that is as fierce as a tiger?']

(Kassim, 1997, p. 396)

Hang Tuah is able to meet te challenge when he succeeds in taming the horse. His success awes Kisna Rayan, who then realizes that Hang Tuah is an intelligent, daring, and agile warrior who will take on a challenge. His awe is reflected in the following passage:

Maka titah Kisna Rayan, "Hai Laksamana, sungguhlah engkau hulubalang besar maka engkau dapat naik kuda ini; kerana dalam hulubalangku yang banyak berpuluh-puluh keti ini, seorang pun tiada bercakap menaiki dia." Maka sembah Laksamana, "Daulat Tuanku Syah Alam, dalam itu pun dengan daulat Syah Alam maka dapat patik naik kuda ini"

[And Kisna Rayan said, "O Laksamana, you are truly a great warrior to be able to ride this horse; for among my warriors who number hundreds of thousands, not even one has been able to ride it." And the Laksamana 
replied, "Your Majesty, king of the world, it is only because of your powers as king of the world that I am able to do so"]

(Kassim, 1997:397).

This convinces Kisna Rayan that the diplomatic relations offered by Melaka are no trifle but are serious. Therefore, Kisna Rayan opens the door for diplomacy with Melaka. He is sure that the diplomatic relations will benefit both sides, especially in terms of politics and the economy, apart from restoring family relationships. Nevertheless, Hang Tuah continues to use interpersonal communication as a means to resolve conflicts in maintaining diplomatic relations.

Apart from mastering a foreign language, a person's character also influences one's interpersonal communication. The characteristics shown by ordinary citizens reflect the characteristics of their rulers, and vice versa. Hang Tuah, through his body language and his words, is able to influence Kisna Rayan's vision and emotion. Kisna Rayan often observes Hang Tuah, and becomes greatly taken by him. In fact, their relationship grows closer by the day, even though they have just got to know each other. According to Noriah Taslim (1995, p. 9), Hang Tuah's sweet words and courteous behaviour make "gemar serta kasih segala melihat dia," [everyone who sees him loves him], in the words of the writer of Hikayat Hang Tuah. This is supported by Zainal Abidin, (2010, p. 75), who is of the opinion that every sultan or king who meets him is attracted to Hang Tuah's mild and courteous manner.

Setelah dilihat oleh Kisna Rayan akan Laksamana datang itu, maka diperamat-amatinya oleh Kisna Rayan Laksamana berjalan itu, terlalu muhtasyam dengan merendahkan dirinya, terlalu baik barang lakunya dan sikapnya berjalan di hadapan Kisna Rayan itu. Maka fikir baginda, 'Adapun Laksamana itu terlalu baik sekali sikapnya, patut menjadi hulubalangku dan seratus buah negeri dipegangnya dan duduknya di atas segala hulubalangku'

[When Kisna Rayan saw the Laksamana approaching, he observed the ways the Laksamana walked, with an great honour through humility, his manners exceedingly fine and courteous, as he passed before Kisna Rayan. And His Majesty thought to himself, 'The Laksamana is of a very 
fine nature, I should make him my warrior, and one hundred territories under his command, and he chief among my warriors']

(Kassim, 1997, p. 397)

Hang Tuah's skills in interpersonal communication help resolve the conflict between Kisna Rayan and the Sultan of Melaka. The former agrees to maintain a relationship with Melaka. This is proven when Hang Tuah and Maharaja Setia are awarded suits of gold cloth, given a place to stay, and are shown the greatest hospitality in the Indian kingdom.

Maka Laksamana dan Maharaja Setia pun dianugerahi persalin oleh Kisna Rayan pakaian keemasan selengkapnya. Maka titah Kisna Rayan, "Hai Nala Sang Guna, beri tempat singgah akan Laksamana dan Maharaja Setia ini; peliharakan baik-baik; dan segala Melayu ini beri musaranya. Selagi duduk di Benua Keling ini beri ia makan dan pakai. Di atas Nala Sang Guna dan Syahbandar, aku tahu”

[And so the Laksamana and Maharaja Setia were given a complete suit of clothing of golden hue. And Kisna Rayan said, "O Nala Sang Guna, prepare a place for the Laksamana and Maharaja Setia to stay; look after them well; and to all the Malays, give them their dues. For as long as they remain in this land of India, give them food and clothing. With this I charge you, Nala Sang Guna, and Syahbandar,"]

(Kassim, 1997, p. 394).

And:

Maka titah baginda kepada bendahara Mangkubumi, "Apa bicara kita hendak mengutus ke Benua China? Siapa yang patut pada Bendahara?" Maka sembah Bendahara, "Siapa lain daripada Laksamana, kerana Laksamana itu tahu akan perintah segala raja-raja yang besar-besar; tambahan ia orang bijaksana." Maka titah Kisna Rayan, "Pada bicara kita pun demikian, kerana raja Benua China itu raja besar. Kita lihat Laksamanalah yang dapat kita titahkan ke Benua China itu." Maka raja pun sebagai memandang Laksamana, kerana baginda sangat berkenan akan Laksamana. 
[And His Majesty addressed the bendahara Mangkubumi, "What word shall we send to the land of China? Who do you think is most suitable as envoy, Bendahara?" And the Bendahara replied, "Who else but the Laksamana, for it is the Laksamana who is knowledgeable in the speech of great kings, and he himself is of great wisdom.” And Kisna Rayan said, "Our opinion is the same, for the king of China is an emperor. We see that the Laksamana is most suited to be the envoy that we can send to China." And he looked at the Laksamana, for he was most taken with the Laksamana.]

(Kassim, 1997, p. 402).

Hang Tuah is entrusted with acting as envoy of the Indian kingdom in its dealings with China, and important task in the dealings of this kingdom. In the opinion of the ruler, Hang Tuah is the right person to act as envoy and pull off a successful diplomatic mission. Ahmad Samin (2010, p. 108) states that without Hang Tuah's air of authority, it is difficult to imagine that Hang Tuah, once an ordinary servant, was given such a great honour from not only the king of Melaka but also various foreign rulers.

\section{THE CONFLICT OF LIGOR USURPATION OF POWER IN KEDAH}

Conflicts involving usurpation of power are a kind of encroachment in administration. If not handled properly, such conflicts will drag on. This is precisely what takes place in the kingdom of Kedah, where Tengku Ya'akob, also known as Tengku Ambon, is the son of Tengku Dhia'uddin, the crown prince of Kayang (Muhammad Hassan Dato' Kerani Muhammad Arshad, 1968, p.144). His request to rule Kayang and Setol (territories of Siam) in his father's stead is not granted by the Sultan of Kedah. Subsequently, Tengku Ya'akob carries a grudge against the Sultan of Kedah and plots with Ligor to topple the Sultan of Kedah, allowing Kedah to be annexed by the kingdom of Ligor. Tengku Ya'akob reveals the secrets of Kedah's defence to Ligor.

Maka tiga kali Tengku Ya'akob, Raja Muda, masok mengadap duli baginda bermohon supaya permintaannya itu di-luluskan, akan tetapi tiada juga di-luluskan baginda. Oleh kerana hal yang demikian duli Tengku Ya'akob, Raja Muda, pun bermuafakat dengan orang2-nya berangkat pergi mengadap Raja Ligor yang bernama Chao Phya Nongkon Sri 
Tamrat di dalam negeri Ligor serta memberitahu kapada Raja Ligor beberapa jalan yang senang jika hendak mengambil negeri Kedah itu. Maka dudok-lah Tengku Ya'akob, Raja Muda di-negeri Ligor.

[Three times Tengku Ya'akob, the crown prince, sought an audience with the king asking his request be granted, but he was refused. Because of this, Tengku Ya'akob, the crown prince, plotted to see Chao Phya Nongkon Sri Tamrat, the King of Ligor, in the kingdom of Ligor, and to inform the King of Ligor of the easiest way to conquer the kingdom of Kedah. Thus Tengku Ya'akob, the crown prince, came to stay in Ligor.]

(Muhammad Hassan, 1968, pp.144-145)

Much effort is made to regain Kedah but in vain. Day after day, more and more citizens of Kedah are killed. Seeing this, Tengku Anom, as the representative of Kedah, wishes to stop this from continuing, and seeks a way to do end the conflict. Prior to this, Tengku Anom had once served as envoy when presenting gold and silver flower trees to Ligor. The reestablishment of good relations is beneficial to both sides. Among other things, it limits the spread of foreign influence in the north of the Malay Peninsula, as well as ending the disturbances accused by nearby kingdoms. Therefore, to overcome this conflict, Tengku Anom chooses to apply interpersonal communication. This is because this method is more diplomatic.

Tujuan-nya yang pertama ialah hendak mengambil balek negeri Kedah ini dengan atoran yang halus dan yang kedua-nya ia-lah hendak memeliharakan orang2 Kedah yang di-bawa pergi ka-Ligor oleh orang2 Siam.

[His first aim was to regain Kedah with subtle strategies, and his second, that he should be given power over subjects from Kedah who had been transported to Ligor by the Siamese.]

(Muhammad Hassan, 1968, p. 152)

The kind of interpersonal communication that Tengku Anom employs is face-to-face meetings. Tengku Anom meets Phya Sina Nunchit, the son of the King of Ligor who ruled Kedah at the time, in order to get a letter of recommendation to seek audience with the King of Ligor, stressing that 
he was never involved with the internal conflict in Kedah at the time. After convincing Phya Sina Nunchit, a letter of recommendation is obtained in which Tengku Anom is praised and his non-involvement in the internal conflict in Kedah is highlighted. The "power of the voice" in convincing is one of the factors that strengthens the interpersonal communication of Tengku Anom. According to Zawiyah (2009), interpersonal communication skills involve the ability to meet the needs of different individuals while maintaining the quality of interpersonal communication. The effects can be seen in the following passage:

... Maka Tengku Anom pun ma'alumkan kapada Phya Nunchit yang ia tiada suka hendak dudok di-negeri Kedah, sembah-nya, "Perhamba suka hendak dudok menjadi hamba Chao Phya Nongkon Sri Tamrat di Ligor hingga sampai habis umor perhamba, kerana perbuatan orang2 Kedah dudok perbuat. Yang demikian itu perhamba tiada suka sa-kali, jikalau perhamba dudok lagi di Kedah ini nama perhamba pun akan menjadi jahat kapada Chao Phya pada hal perhamba sangat merasa lagi kaseh akan Chao Phya dan segala putera2 Chao Phya."

Maka Tengku Anom pun minta suatu surat dari Phya Sina Nunchit bagi membenarkan ia masok mengadap Chao Phya Raja Ligor. Maka Phya Sina Nunchit pun sangat suka hati-nya mendengar Tengku Anom memuji2 bapa-nya dan memuji2-nya itu. Maka di dalam surat ia memuji2 Tengku Anom dengan mengatakan Tengku Anom ada-lah sa-orang yang baik dan tidak masok champor di dalam peperangan bersama orang2 Kedah dan lain2nya

[... So Tengku Anom informed Phya Nunchit that he did not like to remain in the kingdom of Kedah, saying "I wish to be the subject of Chao Phya Nongkon Sri Tamrat in Ligor till the day I die, because of the ways of the people of Kedah. I do not at all like what they do, and fear that if I remain in Kedah, I will be just as treacherous to Chao Phya, whereas I love Chao Phya and all his princes."

And Tengku Anom then asked for a letter from Phya Sina Nunchit to allow him to have an audience with Chao Phya, the King of Ligor. And Phya Sina Nunchit was infinitely pleased hearing Tengku Anom showering praise upon his father and himself. Thus, in his letter he praised Tengku 
Anom as a person of goodness, and as one who had not had a hand in the war between Kedah and the others.]

(Muhammad Hassan , 1968, pp.152-153)

The second type of interpersonal communication employed by Tengku Anom involves posture and body language, gestures and facial expressions, clothing and appearance, as well as tone and pitch of voice. Tengku Anom seeks an audience with the King of Ligor every day and does good to attract Chao Phya Nongkon Sri Tamrat. Tengku Anom displays fine, courteous language and takes care of his appearance and how he comes across when facing king Chao Phya Nongkon Sri Tamrat, with the result that the latter Chao Phya Nongkon Sri Tamrat is very impressed by the positive qualities displayed by Tengku Anom, appointing him as the leader of the people of Kedah, who were conquered by the Siamese during wars between the two kingdoms. Among the passages that deal with the interpersonal communication involving body posture and movement, gestures and facial expressions, clothing and appearance, as well as voice are:

\section{Example 1:}

Hatta, sa-lama Tengku Anom dudok di-Ligor itu hari2-lah ia masok mengadap Chao Phya Ligor itu serta melakukan pekerjaan2 yang diperkenan oleh Chao Phya Ligor. Tiada berapa lama kemudian Chao Phya Ligor pun mmengambil Tengku Anom itu menjadi memalik-nya serta diserahkan segala orang2 Kedah di dalam negeri Ligor itu kapada Tengku Anom Paduka Raja yang telah di-angkat memjadi ketuha mereka itu.

[So, for as long as Tengku Anom stayed in Ligor, he would have audience with Chao Phya of Ligor and do everything that pleased Chao Phya of Ligor. Not long after, Chao Phya of Ligor took Tengku Anom as his subordinate, and presented all the subjects of Kedah who were in the kingdom of Ligor to Tengku Anom Paduka Raja, whom he appointed as their leader.]

(Muhammad Hassan, 1968, p.155) 
Example 2:

... Maka pada keesokan hari-nya Chao Phya Raja Ligor bertitah kepada Tengku Anom, "Sekarang boleh Tengku Anom Raja Jambangan terima ambil negeri kedah itu dan memerentah-nya". Maka sembah Tengku Anom "Perhamba tiada suka menjadi raja. Perhamba suka menjadi hamba Chao Phya di sini sampai habis umor perhamba"

[... On the next day, Chao Phya, the King of Ligor, spoke to Tengku Anom, "Now Tengku Anom, Raja Jambangan, I present you with the country of Kedah for you to rule". And Tengku Anom replied, "I do not wish to be king, Sire. I will be your humble servant until the day I die"]

(Muhammad Hassan, p.158 )

The King of Ligor trusts Tengku Anom so much that in the end he presents Kedah to the latter. In return, the King of Ligor asks that he be sent gold and silver flower trees three years once, as is shown in the following passages:

Example 3:

Sa-telah dudok berkata-kata sa-katika maka titah Chao Phya Ligor kapada Tengku Anom, "Pada hari ini Tengku Raja Jambangan terima balek-lah negeri Kedah serta sakalian ta'alok-nya dan tiada lagi termasok di-bawah perentah Siam, melainkan Tengku Anom mahu-lah hantarkan bunga emas, bunga perak tiap2 tiga tahun sa-kali mengikut adat lama seperti yang telah diadatkan oleh Raja-raja yang terdahulu sa-bagai tanda kaseh berkasehan dan bersetia"

[After some small talk, Chao Phya of Ligor said to Tengku Anom, "On this day, Tengku Raja Jambangan, I return the country of Kedah and all its territories to you, henceforth it is no longer a domain of Siam, unless you, Tengku Anom, wish to send gold and silver flowers every three years according to the old custom, established by the kings of old as a sign of love and loyalty"] 
Example 4:

Maka sembah Tengku Anom, "Sangat2-lah berat tanggungan perhamba kerana di-kurniakan negeri kapada perhamba, lebeh2 lagi kerana perhamba ini tiada harti memerintah negeri"

[And Tengku Anom replied, "This is a great weight upon me, to be given a the rule of a country, for I have not the heart to rule"]

(Muhammad Hassan, 1968, p. 160)

This is what Tengku Anom had been waiting for, and the reason he had built the trust and confidence of the King of Ligor in his abilities as a representative of Kedah. Meanwhile, the willingness with which the King of Ligor returns Kedah to its people convinces Tengku Anom that his interpersonal communication is on the right track. The acceptance of terms set by the King of Ligor is also an interpersonal response by Tengku Anom. This response is in line with the opinions of Ainon dan Abdullah (2005), who state that effective interpersonal communication requires cooperation of the speaker as well as the listener. Without the right kind of interpersonal communication, the Ligor kingdom would not have allowed Tengku Anom to remain in Ligor.

The face-to-face meetings, character and wisdom of Tengku Anom attract the attention of the King of Ligor. Without any force or compulsion whatsoever, Tengku Anom successfully resolves the conflict between the two kingdoms. The King of Ligor returns power over Kedah, which he had conquered earlier, and agrees to maintain diplomatic relations among the two kingdoms, with some conditions, that is, that Kedah send gold and silver flower trees to Ligor three years once. Tengku Anom agrees to fulfil these conditions and the implication is that the diplomatic relations between Kedah and Ligor continue as before.

\section{IMPLICATIONS}

The implications of this study are that effective interpersonal communication is capable of resolving any conflicts that may arise among governments. Envoys appointed by governments are a means by which interpersonal communication is carried out. Therefore, each envoy must be knowledgeable in this field. Apart from this, this study also shows that successful interpersonal 
communication can strengthen relationships and bring attention to the culture and customs of a kingdom, as well as highlight the intellect of the Malay rulers of old in diplomatic relations.

\section{CONCLUSION}

The discussion of interpersonal communication as a mechanism to resolve conflicts in the Malay Sultanates has shown that one of the main methods used in resolving conflicts, especially in forming or strengthening diplomatic relationships is through the use of envoys. Interpersonal communication tests an appointed individual's in terms of linguistic, communicative, intellectual and physical abilities. All four of these elements combine to attract the attention of foreign rulers, and it is found that these elements influence the decisions of these rulers on whether to maintain or break off diplomatic relations.

Hang Tuah, as envoy of Melaka, was able to establish diplomatic relations with an Indian kingdom, while Tengku Anom successfully reestablished relations between Kedah and Ligor, finally succeeding in the return of Kedah to its rightful heirs. Both these envoys employed nine important elements in interpersonal communication, that is, posture and body language, gestures or facial expressions, clothing and appearance, as well as voice, and pausing to allow the listener to become involved. Such implementation of interpersonal communication by the envoys allowed the two kingdoms, Melaka and Kedah, to prosper. This also proves that interpersonal communication is a mechanism that can resolve conflicts in diplomatic relations among governments.

\section{REFERENCES}

A.Samad Ahmad (ed.). 2010. Sulalatus Salatin: Sejarah Melayu. (Edisi Kesepuluh). Kuala Lumpur: Dewan Bahasa dan Pustaka.

Ab. Aziz Yusuf. 2003. Gelagat organisasi: Teori, isu dan aplikasi. Kuala Lumpur: Pearson (M) Sdn. Bhd.

Adler, R. B., Rosenfeld, L. B. \& Towne N. 1999. Interplay: The process of interpersonal communication. Fort Worth: Harcourt Brace.

Ahmad Samin Siregar. 2010. Hang Tuah dari sudut pandangan Indonesia, wira Melayu yang berwibawa. In Mohd Yusoff Hashim (Ed.), Hang Tuah wira Melayu. Melaka: Institut Kajian Sejarah dan Patriotisme Malaysia. 
Ainon Mohd \& Abdullah Hassan. 2005. Kuasa berfikir kreatif. Shah Alam: Malindo Printers.

Anwar Ridhwan. 2009. Belajar bahasa asing tanpa kontroversi. http://1anwarridhwan. blogspot.com.

Bustan al-Salatin (Universiti Malaya, MS 41)

Hassan Ahmad. 2006. Ke arah kelahiran Melayu glokal. Shah Alam: Alaf 21 Sdn. Bhd.

Ishak Mad Shah. 2006. Kepimpinan dan hubungan interpersonal dalam organisasi. Skudai: Universiti Teknologi Malaysia.

Ishak Mad Shah. 1999. Pengenalan kepada psikologi industri. UTM, Skudai: Jabatan Pembangunan Sumber Manusia, Fakulti Pembangunan Dan Pengurusan Sumber Manusia.

Kassim Ahmad (Ed.). 1997. Hikayat Hang Tuah. Kuala Lumpur: Dewan Bahasa dan Pustaka dan Yayasan Karyawan.

Lim Kim Hui. 2005. Pemikiran strategi Melayu dalam Hang Tuah's strategy mind: sebuah pendekatan falsafah antara-budaya. Kertas kerja dalam Majlis Bicara Karya. Dewan Seminar, Tingkat 2, Dewan Bahasa dan Pustaka, Kuala Lumpur.

Lokman Abdul Samad. 2001. Hikayat Hang Tuah: Suatu pembicaraan karya agung dari pelbagai aspek. Kota Kinabalu: Pusat Penataran Ilmu dan Bahasa, Universiti Malaysia Sabah.

Mansor, A. S., Ramli, M., \& Shawaluddin, A. 1984. Pengantar komunikasi. Pulau Pinang: Universiti Sains Malaysia.

Mohammad Yusof. 2009. Kemahiran komunikasi. Kuala Lumpur: Dewan Bahasa dan Pustaka.

Mohd Jamil Mukmin. 2011. Sejarah hubungan diplomasi Kerajaan Melayu: Satu tinjauan. Jurnal IKSEP, 2, 71-90.

Mohd Safiee, I., Ashari, S., Siti Zahara, M. A., Mohd Zaid, M., Ahmad Rizal, M., \& Latifah, M. A. 2008. Komunikasi interpersonal dalam pengajaran di kalangan guru-guru teknikal di Sekolah Menengah Teknik di elaka. National Conference on Student Development 2008, Universiti Teknologi Malaysia, 22-23 October 2008.

Muhammad Hassan Dato' Kerani Muhammad Arshad. 1968. Al-Tarikh Salasilah Negeri Kedah. Kuala Lumpur: Dewan Bahasa dan Pustaka.

Newstorm, J. \& Davis, K. 1997. Organisational behaviour: Human behaviour at work. New York: McGraw-Hill Higher Education.

Noriah Mohamed. 1997. Pengenalan tambahan dalam Hikayat Hang Tuah. (Edisi Karya Agung.). Kuala Lumpur: Yayasan Karyawan dan Dewan Bahasa dan Pustaka. 
MALAY LITERATURE VOLUME 31 NUMBER 1 JUNE 2018

Noriah Mohamed. 2010. Hang Tuah keunggulan peribadi Melayu. In Mohd Yusoff Hashim (ed.), Hang Tuah wira Melayu. Melaka: Institut Kajian Sejarah dan Patriotisme Malaysia.

Noriah Taslim. 1995. Hikayat Hang Tuah: Sebuah kitab peraturan segala hamba. Dewan Sastera, 6-11.

Pearson, J.C \& Nelson, P. E. 2000. An introduction to human communication understanding dan sharing. (Eighth Edition). New York: McGraw-Hill Higher Education.

Salmah Jan Noor Muhamad. 2015. Warkah sebagai medium diplomatik Kesultanan Nelayu dalam menjalankan hubungan dengan kuasa Barat. Jurnal Melayu. No. 14 (1) 2015, 136-148.

Zainal Abidin Borhan. 2010. Peranan Hang Tuah dalam memartabatkan bahasa Melayu. In Mohd Yusoff Hashim (Ed.), Hang Tuah wira Melayu. Melaka: Institut Kajian Sejarah dan Patriotisme Malaysia.

Zawiyah Mohammad Yusof. 2009. Kemahiran komunikasi. Kuala Lumpur: Dewan Bahasa dan Pustaka.

Zulkifli Yusof. 2000. Sukarkah komunikasi anda? Seni berhubung dengan orang lain. Kuala Lumpur: Utusan Publications \&Distributors Sdn. Bhd.

Received: 16 March 2018

Accepted: 18 April 2018 